\title{
Chrysoprase and Prase Opal from HaNeti, Central TaNZaNia
}

\author{
James E. Shigley, Brendan M. Laurs, and Nathan D. Renfro
}

Commercial quantities of gem-quality chrysoprase and green prase opal (nickel-bearing chalcedony and common opal, respectively) have been recovered from altered serpentinite deposits near Haneti, Tanzania. Material studied for this report came from the largest mine, located on top of lyobo Mountain, which has been actively exploited for two decades. Although somewhat similar in color and appearance, chrysoprase and prase opal can easily be distinguished from one another by differences in refractive index ( 1.55 vs. 1.45 ) and specific gravity ( 2.60 vs. $\sim 2.11)$. Chrysoprase makes up the vast majority of the output, and the mine shows good potential for continued production.

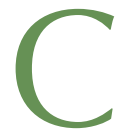

hrysoprase and prase opal are nickel-containing green varieties of chalcedony and nonplay-of-color (common) opal, respectively. Both have been used as gem materials for thousands of years. Chrysoprase was described as being the "most prized" type of chalcedony by Webster (1994, p. 233). Central Tanzania is an important contemporary source of both these gems. The Tanzanian materials were first briefly described by Gübelin (1975, pp. 76-78) and Schmetzer et al. (1976). These reports were followed by a characterization of the green prase opal by Koivula and Fryer (1984), and a more detailed study of the chrysoprase by Kinnunen and Malisa (1990).

See end of article for About the Authors and Acknowledgments. Gems \& Gemology, Vol. 45, No. 4, pp. 271-279.

(C) 2009 Gemological Institute of America
This article briefly describes the geology, mining, and gemological characteristics of high-quality Tanzanian chrysoprase and prase opal from the Iyobo Mountain mine near Haneti (figure 1). This mine is operated by Dimitri Mantheakis, who hosted two of the authors (JES and BML) there in May 2008. Although both materials have also been found in several other parts of the world (table 1), Tanzania is probably the most important source of chrysoprase after Australia.

\section{BACKGROUND}

The green color of chrysoprase has long been thought to be caused by one or more submicroscopic green nickel compounds $\left(\right.$ as $\left.\mathrm{Ni}^{2+}\right)$. While this idea has been discussed for more than two centuries, the exact nature of these nickel compounds continues to be debated (Natkaniec-Nowak et al., 1989). Some researchers suggested it was a nickel oxide (possibly the mineral bunsenite; see Heflik et al., 1989), but subsequent spectroscopic and high-magnification imaging studies disproved this idea (see Rossman, 1994; Gaweł et al., 1997). Most others have ascribed the coloring agent to layered or framework hydrated nickel silicates (such as kerolite) or nickel-containing clay minerals (such as garnierite, lizardite, or saponite; see Rossman, 1994, pp. 458-459; Nagase et al., 1997; Dyrek et al., 2001; Sachanbiński et al., 2001; Sojka et al., 2004).

The nickel compound(s) occur as tiny, colloidal particles that are dispersed as inclusions throughout the host silica matrix. The presence of a small amount of iron $\left(\right.$ as $\left.\mathrm{Fe}^{3+}\right)$ can modify the color of chrysoprase to be more yellowish green, whereas light scattering from microdefects or small particles in the translucent material (the "Tyndall Effect") has been suggested as the cause of the more bluish green 


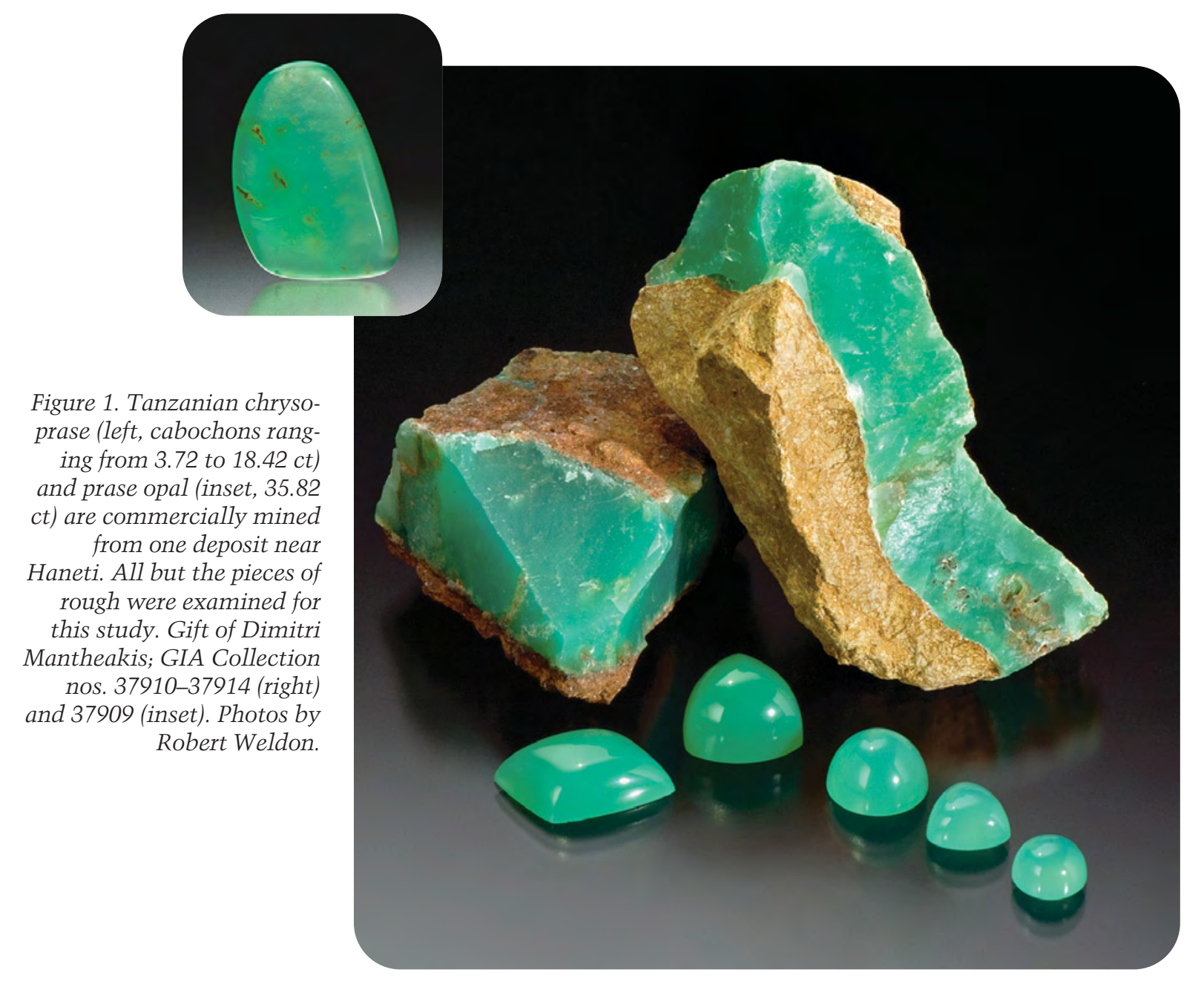

appearance seen in reflected light (Sachanbiński et al., 2001). Gawel et al. (1997) studied chrysoprase from several localities, and concluded that those samples with a lower degree of crystallinity tended to have higher nickel contents and a more intense green color. Presumably, dispersed particles of nickel-containing minerals also color the green prase opal from Tanzania, since the visible spectra of both materials are similar (see Results section). Schmetzer et al. (1976) described this material as being opal-CT.

Because of their opaque-to-translucent green appearance and ability to take a good polish, both chrysoprase and prase opal have been used as substitutes for jade. Dyed green agate and green glass have occasionally been used to imitate chrysoprase (O'Donoghue, 2006). Also known is a chromiumcolored green chalcedony found in Australia, Bolivia, and Zimbabwe (material from the last has been referred to as mtorolite; see Phillips and Brown, 1989; Hyršl and Petrov, 1998; Hyršl, 1999; Willing and Stocklmayer, 2003). An opaque-to-semitranslucent yellow-green carving material from Australia, sold under the name "lemon chrysoprase," has been described as a rock consisting of magnesite and quartz (Johnson and Koivula, 1996) or of both minerals along with chrysoprase (Henn and Milisenda, 1997). All these other materials have gemological properties that allow them to be distinguished from chrysoprase and prase opal.

\section{OCCURRENCE AND DESCRIPTION OF THE TANZANIAN MATERIAL}

Location. Chrysoprase has been found on three adjacent hills that lie $\sim 12 \mathrm{~km}$ southeast of the village of Haneti and $12 \mathrm{~km}$ north of the village of Itiso. Haneti is $75 \mathrm{~km}$ north of Dodoma along Highway A104 (figure 2). The mine operated by Mr. Mantheakis is located near the top of the southernmost of the three hills (known as Iyobo Mountain; figure 3 ), at $5^{\circ} 31.90^{\prime} \mathrm{S}, 35^{\circ} 59.33^{\prime} \mathrm{E}$ and at an elevation of $1,452 \mathrm{~m}$. The area is accessible during the dry season (which runs April through November) by a dirt road from Dodoma to Haneti, and from there to the mine site by a rough dirt track. 
Geology. According to Kinnunen and Malisa (1990), rocks in the area of the Haneti deposit are of Archean age and consist of metamorphosed ultramafics that form the three chrysoprase-bearing hills. These are aligned in a northwesterly direction, which marks the orientation of regional fracture/shear zones. They described the dominant rock type hosting the chrysoprase as a silicified and ferruginized (silica- and ironaltered) serpentinite.

TABLE 1. Other world sources of chrysoprase and prase opal.

\begin{tabular}{|c|c|c|}
\hline Locality & Geologic setting & Reference \\
\hline \multicolumn{3}{|l|}{ Chrysoprase } \\
\hline $\begin{array}{l}\text { Marlborough, Queensland, } \\
\text { Australia }\end{array}$ & $\begin{array}{l}\text { Weathered and laterized } \\
\text { serpentinites or other ultra- } \\
\text { mafic rocks }\end{array}$ & $\begin{array}{l}\text { Brooks (1965), Krosch } \\
\text { (1990), Jones (1992), } \\
\text { O'Brien (1997), Brown } \\
\text { (2000), Downing (2007), } \\
\text { Osmond and Baker (2009) }\end{array}$ \\
\hline $\begin{array}{l}\text { Warrawanda, } \\
\text { Western Australia }\end{array}$ & $\begin{array}{l}\text { Weathered and altered } \\
\text { serpentinites associated } \\
\text { with granites }\end{array}$ & Nagase et al. (1997) \\
\hline $\begin{array}{l}\text { Yerilla Station, } \\
\text { Western Australia }\end{array}$ & $\begin{array}{l}\text { Veins in weathered } \\
\text { siliceous ironstones }\end{array}$ & $\begin{array}{l}\text { Jones (1994a,b), } \\
\text { Brown (2000) }\end{array}$ \\
\hline Niquelandia, Goiás, Brazil & A galena mine (?) & $\begin{array}{l}\text { Kammerling et al. } \\
\text { (1990) }\end{array}$ \\
\hline Saxony, Germany & Not reported & Wittern (2001) \\
\hline $\begin{array}{l}\text { Niigata Prefecture, Honshu, } \\
\text { Japan }\end{array}$ & Not reported & Mindat.org (2009) \\
\hline Sarykul Boldy, Kazakhstan & $\begin{array}{l}\text { Nickel deposit in } \\
\text { weathered serpentinite }\end{array}$ & $\begin{array}{l}\text { Sachanbiński et al. } \\
\text { (2001) }\end{array}$ \\
\hline $\begin{array}{l}\text { Ambatondrazaka, } \\
\text { Madagascar }\end{array}$ & Not reported & Behier (1963) \\
\hline $\begin{array}{l}\text { Szklary, Lower Silesia, } \\
\text { Poland }\end{array}$ & $\begin{array}{l}\text { Nickel deposit in } \\
\text { weathered serpentinite }\end{array}$ & $\begin{array}{l}\text { Drzymała and Serkies } \\
\text { (1973), Niśkiewicz (1982), } \\
\text { Heflik et al. (1989), } \\
\text { Sachanbiński et al. } \\
\text { (2001) }\end{array}$ \\
\hline Southern Urals, Russia & Not reported & Mikhailov (2000) \\
\hline $\begin{array}{l}\text { Tulare County, California, } \\
\text { United States }\end{array}$ & Not reported & O'Donoghue (1995) \\
\hline $\begin{array}{l}\text { Various sites in Arizona, } \\
\text { California, Colorado, } \\
\text { Massachusetts, New York, } \\
\text { North Carolina, Oregon, } \\
\text { Rhode Island, and Vermont }\end{array}$ & Not reported & Mindat.org (2009) \\
\hline \multicolumn{3}{|l|}{ Prase opal } \\
\hline $\begin{array}{l}\text { South Bohemia, } \\
\text { Czech Republic }\end{array}$ & Not reported & Duda et al. (1991) \\
\hline Silesia, Poland & Not reported & $\begin{array}{l}\text { Drzymała and Serkies } \\
\text { (1973), Webster (1994) }\end{array}$ \\
\hline Southern Urals, Russia & $\begin{array}{l}\text { Small vein at a "chrome } \\
\text { mine" }\end{array}$ & Mikhailov (2000) \\
\hline $\begin{array}{l}\text { Napa County, California, } \\
\text { United States }\end{array}$ & Not reported & $\begin{array}{l}\text { "Prase opal in California," } \\
1936\end{array}$ \\
\hline
\end{tabular}

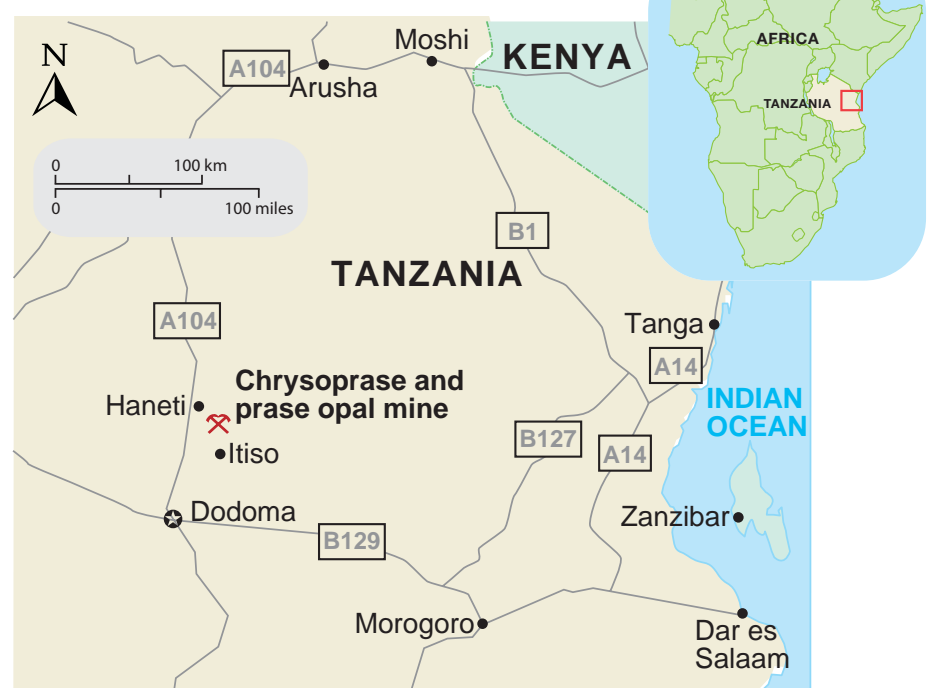

Figure 2. The Haneti chrysoprase and prase opal mine is located in central Tanzania, between Dodoma and Arusha.

Both the chrysoprase and prase opal occur in discontinuous veins up to several centimeters thick and several meters long in the weathered host rock. According to Mr. Mantheakis, the chrysoprase veins appear to be more abundant on the western side and upper portions of Iyobo Mountain; some areas have almost no such mineralization. Within a vein and between different veins, the material can vary from high-quality translucent to low-quality opaque. The best chrysoprase occurs in those areas of a vein that are surrounded by red clay or soil, while poorer-quality material is found where the vein is enclosed by yellowish material. The best-quality prase opal is found in veins within very brittle host rock.

Mining. Although at one time some Ni-rich magnesite veins were prospected in the region, the only mining in the Haneti area has been for chrysoprase-

\section{NEED TO KNOW}

- Chrysoprase and green prase opal are nickelbearing green chalcedony and common opal, respectively.

- They have been mined from lyobo Mountain near Haneti, Tanzania, for more than two decades.

- They are found in veins hosted by altered serpentinite.

- Typically, 7-10 tonnes of "mine-run" chrysoprase is produced annually (3\% suitable for cabochons).

- In the past decade, 1.5 tonnes of "mine-run" prase opal was produced. 


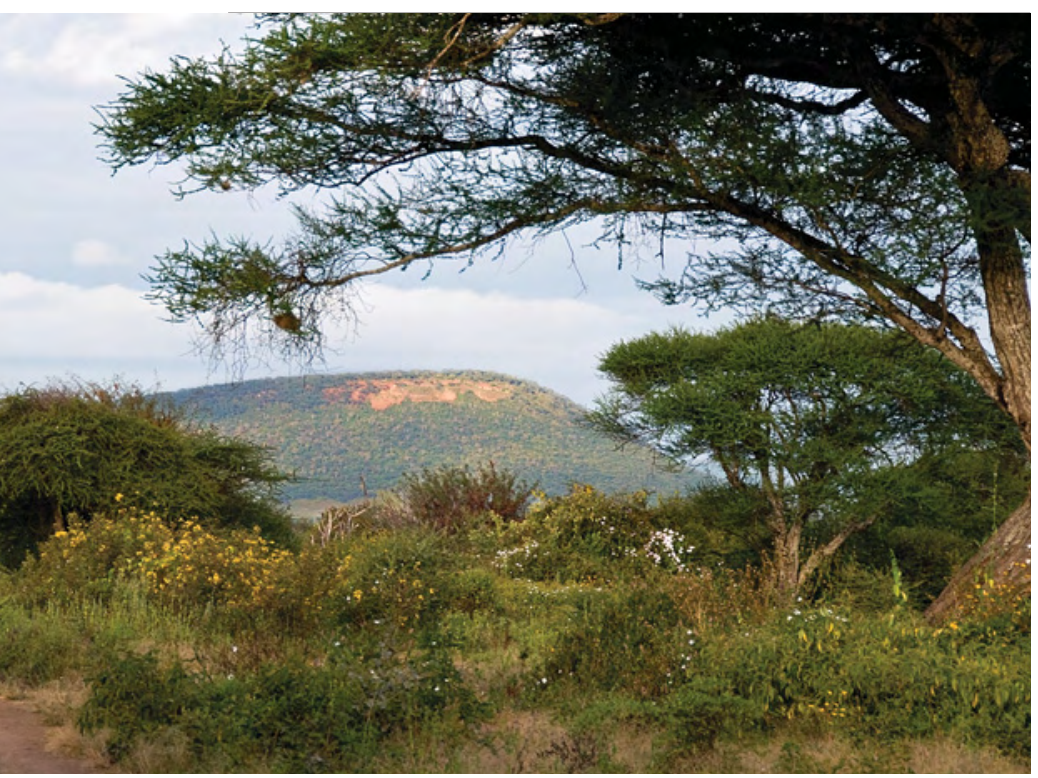

Figure 3. The mine workings are situated on top of Iyobo Mountain and are marked by a row of tailings. Photo by B. M. Laurs.

and prase opal for both gem and ornamental purposes (Kinnunen and Malisa, 1990). According to Mr. Mantheakis, chrysoprase was first found there in the early 1960s, and limited production took place before the concession was nationalized by the government in 1973, after which the mine lay dormant. Mr. Mantheakis, a Tanzanian citizen, reclaimed the mine in 1986, and in 1997 was given full mining rights on the property.
Mining is currently carried out in an open pit (figure 4) at the top of Iyobo Mountain. As many as 35 local people are employed during the dry season. So far, 28 pits have been mined on the mountain, ranging from $\sim 20$ to $\sim 250 \mathrm{~m}^{2}$. Mechanized equipment is used to expose areas containing the gembearing veins, which are then excavated with hand tools (figure 5). The miners follow the veins until they pinch out (figure 6), and the chrysoprase and prase opal are collected by hand (figure 7) and placed into bags for transport to a sorting facility on site.

The chrysoprase production is highly variable, ranging from as little as $100 \mathrm{~kg}$ to as much as 1,000 $\mathrm{kg}$ per month; the typical annual production is $7-10$ tonnes. These quantities are for "mine-run" rough, which includes some chrysoprase in matrix. After sorting and trimming, $20-30 \%$ of the chrysoprase is marketable, but only $3-5 \%$ is of high quality (i.e., translucent, with even, intense color, and suitable for cutting attractive cabochons). The prase opal is much less abundant: In the past decade it has been recovered from only two areas of the mine, which yielded a total of $\sim 1.5$ tonnes of opal in matrix.

The better-quality material is sent to Dar es Salaam for trimming and polishing into cabochons. Some of the lower-quality rough is worked into beads. The material is sold through wholesale and retail outlets in Dar es Salaam, as well as through international trade shows.

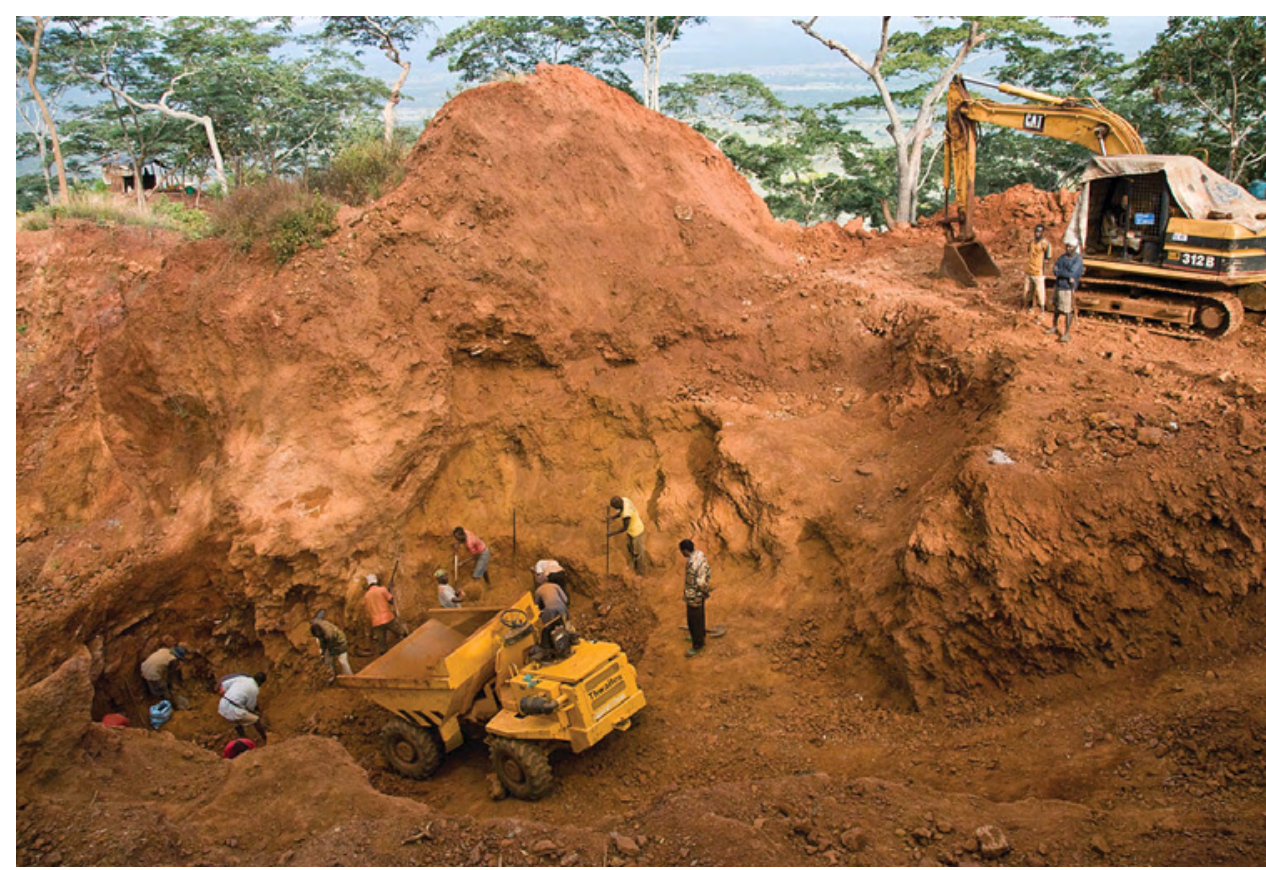

Figure 4. Open-pit mining for chrysoprase and prase opal is performed using an excavator and hauling vehicle. Photo by B. M. Laurs. 


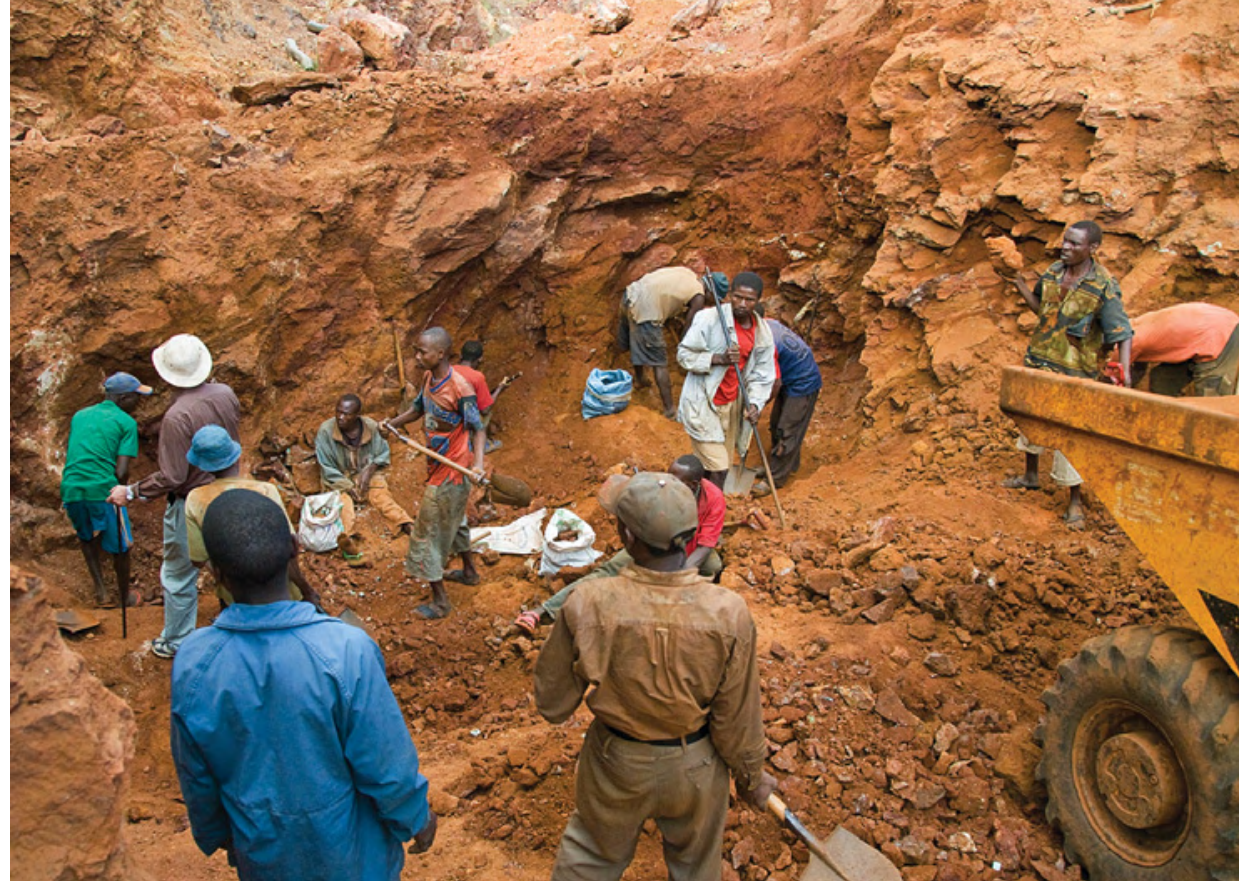

Figure 5. Shovels, pry bars, and picks are used to follow the gem-bearing veins. Photo by B. M. Laurs.

Mr. Mantheakis (pers. comm., 2008) reported that his mining plan is sensitive to the local environment. He places roads to preserve as many of the large trees as possible, and most of the pits are buried as mining proceeds. He estimates that $80 \%$ of the deposit remains to be mined.

\section{MATERIALS AND METHODS}

For this study, we examined nine chrysoprase samples (five cabochons [3.72-18.42 ct] and four preformed or rough pieces weighing up to $8.6 \mathrm{~g}$ ), and five prase opal samples (one 35.82 ct cabochon and four pre-formed or rough pieces weighing up to $7 \mathrm{~g}$ ). All are representative of the better-quality material being produced from Mr. Mantheakis's mine. We documented all the samples with a refractometer, gemological microscope, polariscope, desk-model spectroscope, Chelsea color filter, and standard ultraviolet (UV) lamps.

All the samples were also analyzed by each of the following methods. Qualitative chemical analyses were performed using a Thermo ARL Quant-X energy-dispersive X-ray fluorescence (EDXRF) system with multiple filter, voltage, and current settings appropriate to the elements of interest. Ultravioletvisible-near infrared (UV-Vis-NIR) absorption spectra were recorded over an interval of 250-2500 nm with a Perkin Elmer Lambda 950 spectrometer, using a slit width of $2 \mathrm{~nm}$ and a data sampling interval of $0.5 \mathrm{~mm}$. (Only the $400-700 \mathrm{~nm}$ region is shown in the results, since this is the region of greatest interest for investigating the origin of color.) Infrared spectra were recorded over the 6000-400 $\mathrm{cm}^{-1}$ range with a Thermo Nicolet Magna-IR 760 spectrometer, using a $6 \times$ beam condenser at a resolu- tion of $4 \mathrm{~cm}^{-1}$ and 128 scans per sample to improve the signal-to-noise ratio. We obtained Raman spectra for both materials using a Renishaw InVia Raman microscope with $514.5 \mathrm{~nm}$ laser excitation.

Figure 6. This vein at the chrysoprase/prase opal mine ranges from light green to deep green toward where it pinches out. Photo by B. M. Laurs.

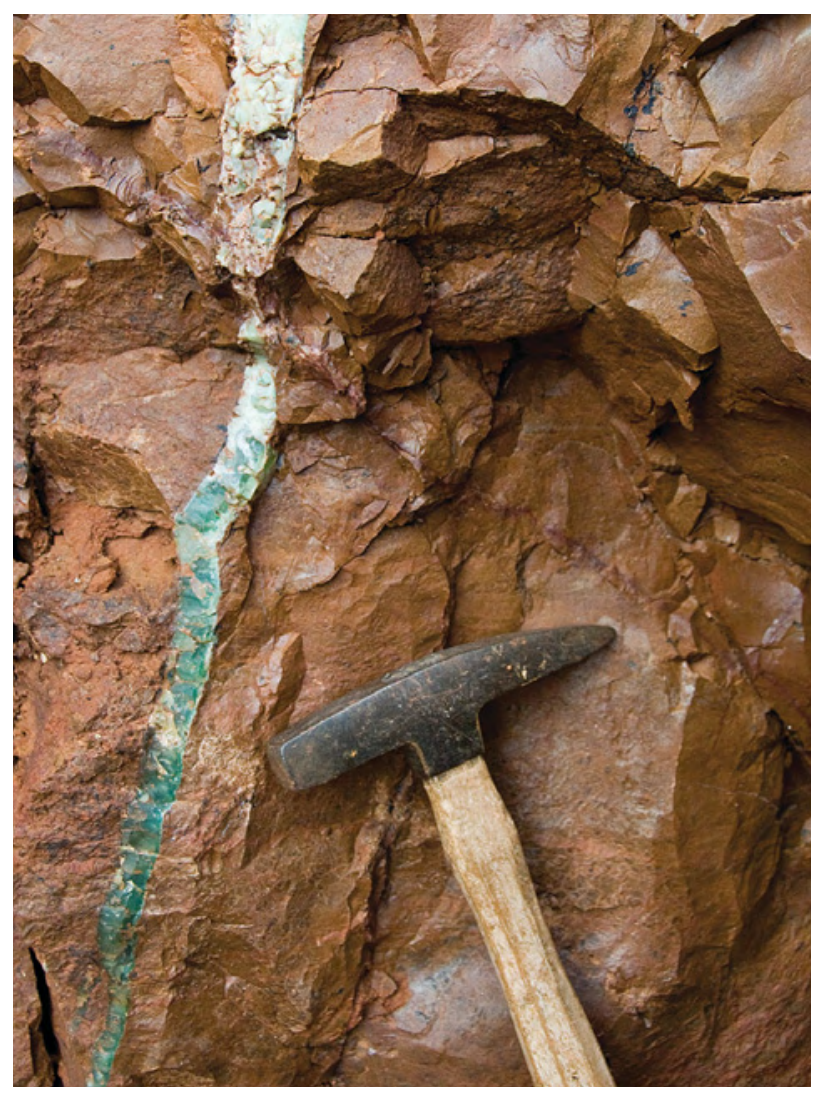




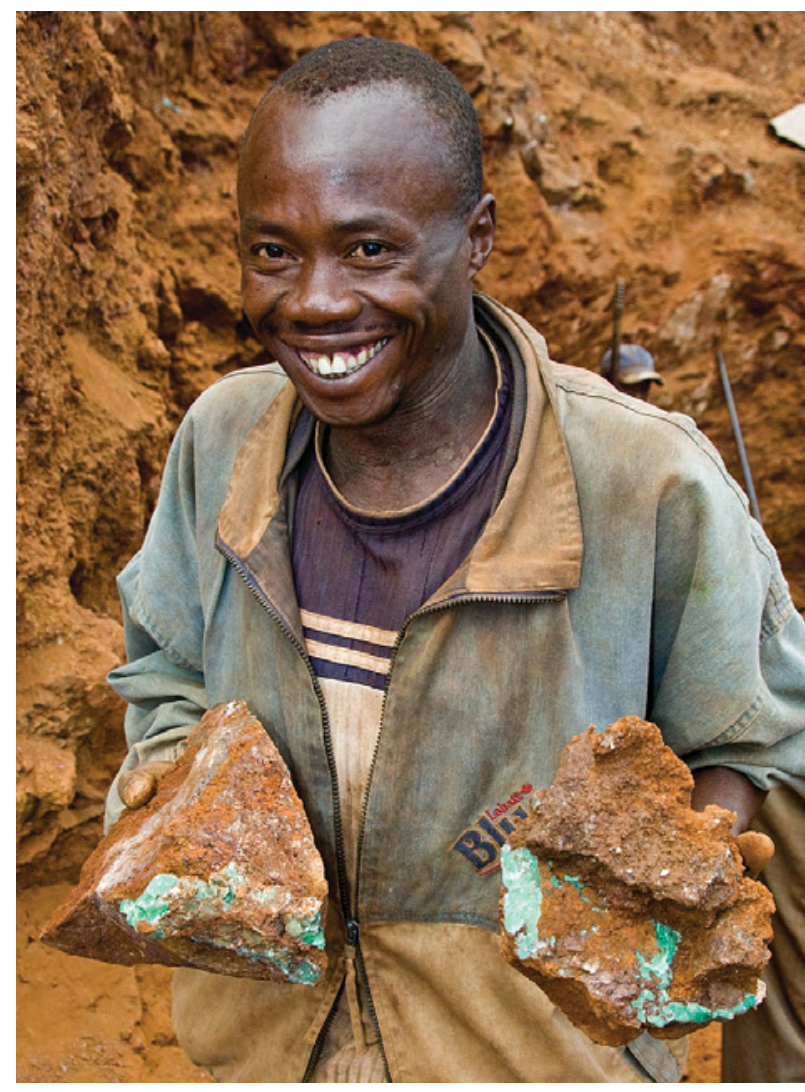

Figure 7. The veins of chrysoprase (shown here) and prase opal typically must be trimmed from the host matrix. Photo by B. M. Laurs.

\section{RESULTS AND DISCUSSION}

Gemological Characteristics. Samples of both materials were light to medium-dark slightly bluish green and opaque to translucent; all displayed a vitreous polish luster. In general, the prase opal was slightly more translucent than the chrysoprase. The color distribution in both materials appeared uniform or very slightly blotchy. In addition, the prase opal displayed small, dark, granular brownish areas along fractures that Raman analysis indicated were most likely goethite; each of these areas tended to be surrounded by a small halo where the adjacent prase opal was yellower (figure 8). The observation that the outline of the halos followed the shape of the dark areas suggests that iron from these inclusions permeated the surrounding prase opal.

The RI and SG values of all tested samples fell within the following ranges, which readily separate the two materials from the Haneti locality:

$\begin{array}{llc}\text { Chrysoprase } & \text { RI } & 1.549( \pm 0.002) \\ & \text { SG } & 2.57-2.63 \\ \text { Prase opal } & \text { RI } & 1.455( \pm 0.004) \\ & \text { SG } & 2.09-2.13\end{array}$

Kinnunen and Malisa (1990) reported similar RI and SG values for the chrysoprase from the Haneti area. These RI values are slightly above those of chalcedony in general, but the SG ranges are consistent with those reported for chrysoprase in the literature (Webster, 1994, pp. 252-253). We could not find properties for prase opal in the literature, but the RI and SG values of our samples fell within the ranges given for opal in general by O'Donoghue (2006).

All samples were inert to both long- and shortwave UV radiation. They exhibited an aggregate reaction when viewed with a polariscope; this reaction was more pronounced for the prase opal. Neither material displayed any reaction when viewed with a Chelsea color filter (i.e., all samples remained green). The desk-model spectroscope revealed broad absorption below $\sim 450 \mathrm{~nm}$ and above $\sim 650 \mathrm{~nm}$ in both materials. These two regions of absorption were more intense, and the intervening region of light transmission narrowed in wavelength range, for the more saturated green samples of both materials. No sharp absorption lines were observed in the spectra of either material.

The gemological properties of both the chrysoprase and prase opal were generally consistent with reports in the literature for samples from the Haneti area and elsewhere. Kinnunen and Malisa (1990) characterized the chrysoprase as displaying a distinct microtexture consisting of disordered silica spherules ( 40-80 $\mu \mathrm{m}$ diameter), formed of concentric layers of quartz, chalcedony, and opal-A, within a silica

Figure 8. This dark inclusion (probably goethite) is surrounded by a yellowish green halo. It appears that iron from the inclusion permeated the surrounding prase opal. Photomicrograph by J. E. Shigley; magnified $15 \times$.

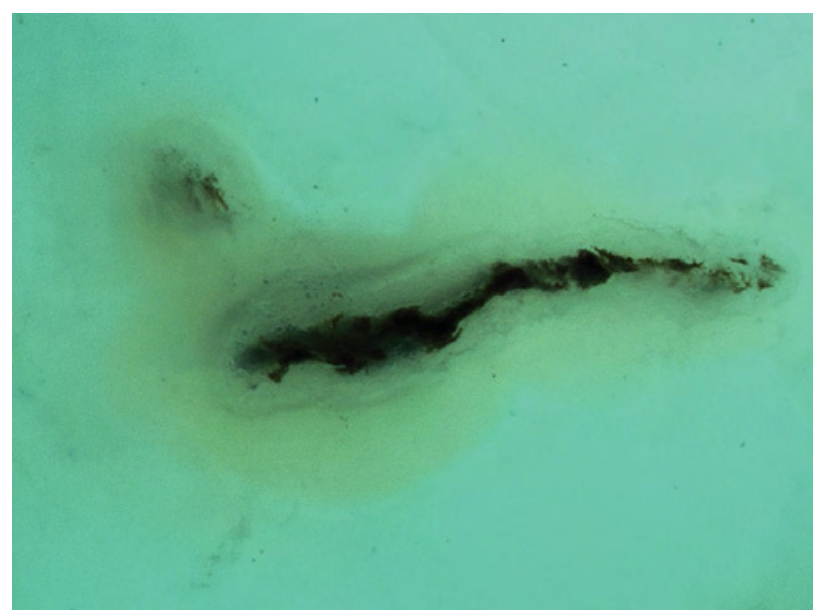




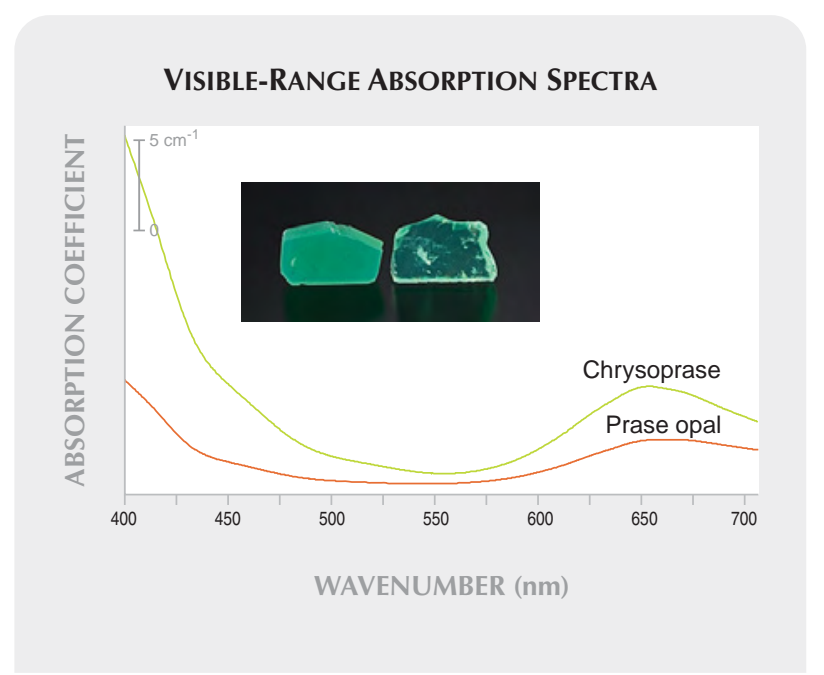

Figure 9. These visible-range spectra are for representative polished slabs of similar thickness of the chrysoprase (path length $1.86 \mathrm{~mm}$ ) and prase opal (path length $1.76 \mathrm{~mm}$ ). Both spectra exhibit regions of absorption below $500 \mathrm{~nm}$ and above 600 $\mathrm{nm}$. The inset photo (by Robert Weldon) shows the similar color of both materials, as well as the greater transparency of the prase opal, on the right.

groundmass. In contrast, they found that the silica spherules in the Tanzanian prase opal were an order of magnitude smaller $(\sim 5-6 \mu \mathrm{m})$. They described the chrysoprase as also containing "cloudy color distributions, clear chalcedony veinlets, whitish dots (microcavities), small fluid inclusions in bypyramidal quartz, and brownish inclusions of host rock" (p. 162) based on microscopic observations $(10 \times-60 \times$ magnification and various lighting conditions). They interpreted the lack of a vapor phase in the liquid inclusions as implying that the chrysoprase formed at a very low temperature and was deposited by repeated evaporation of Si-rich hydrothermal solutions or surface waters along open fractures in the altered serpentinite host rock.

Chemical Analysis. Our EDXRF analyses indicated major amounts of Si and minor $\mathrm{Ni}, \mathrm{Zn}$, and $\mathrm{Fe}$ in both materials. Using atomic absorption spectroscopy, Kinnunen and Malisa (1990) measured 0.55 wt.\% $\mathrm{Ni}$ in the chrysoprase, along with trace amounts of other elements (including the transition metals $\mathrm{Co}, \mathrm{Zn}, \mathrm{Fe}, \mathrm{Mn}$, and $\mathrm{Cu}$ at values up to 120 ppm, and rare-earth elements at 1 ppm or less).

Spectroscopy. The visible-range spectra of both materials showed increasing absorption below about

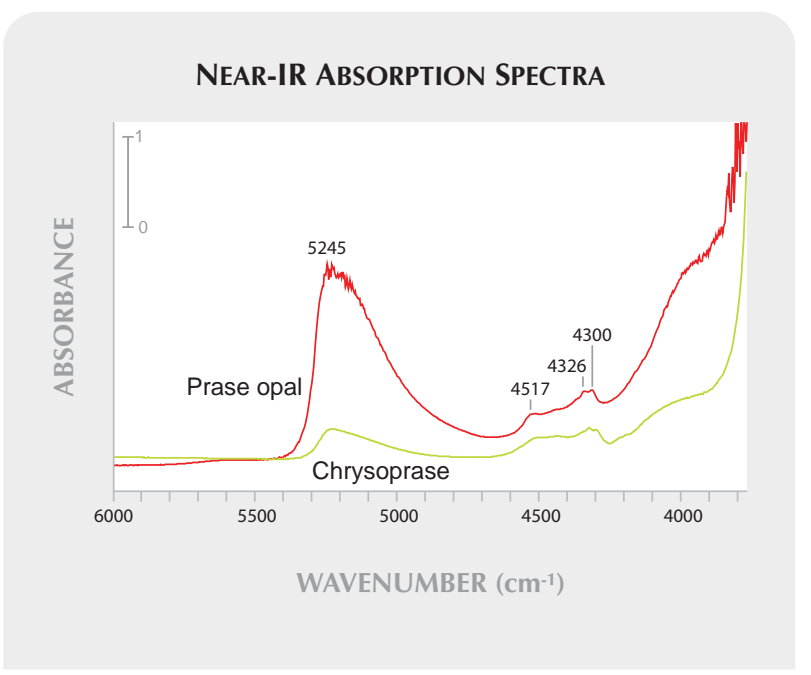

Figure 10. These representative infrared absorption spectra of the chrysoprase and prase opal display a band at $\sim 5245 \mathrm{~cm}^{-1}$ (more intense in the prase opal) and a group of similar features at 4517, 4326, and $4300 \mathrm{~cm}^{-1}$.

$500 \mathrm{~nm}$ and a broad peak centered near $650 \mathrm{~nm}$ (figure 9|, corresponding to the absorption patterns seen with the spectroscope (see also Schmetzer et al., 1976; Sachanbiński et al., 2001). This is consistent with the spectrum for chrysoprase from Tulare County, California (Rossman, 2009). The region of absorption above $650 \mathrm{~nm}$ has been attributed to $\mathrm{Ni}^{2+}$ in octahedral coordination in a silicate mineral (Rossman, 1994, pp. 458-459; there is no indication that this element substitutes for either silicon or oxygen in either the chrysoprase or the prase opal).

The near-infrared spectra were similar for both materials (figure 10), with a broad band at $\sim 5245 \mathrm{~cm}^{-1}$ and a group of features at 4517, 4326, and $4300 \mathrm{~cm}^{-1}$ due to the presence of water molecules or hydroxyl groups in both materials (similar spectra for opals are illustrated in Langer and Flörke, 1974).

In contrast, the Raman spectra of the two materials were very different from one another (figure 11). In the chrysoprase, there were sharp Raman peaks at 1160, 807, 463 (much more intense than the other peaks), 398, 354, and $264 \mathrm{~cm}^{-1}$. All of these features were reported previously in a study of the Raman spectra of microcrystalline silica (including chalcedony) by Kingma and Hemley (1994). The Raman spectra of the prase opal exhibited peaks at 783,671 , and a broader feature at $325 \mathrm{~cm}^{-1}$. Similar features at $\sim 800-780$ and $\sim 325 \mathrm{~cm}^{-1}$ were reported in opals by Ostrooumov et al. (1999) and by Smallwood (2000). 


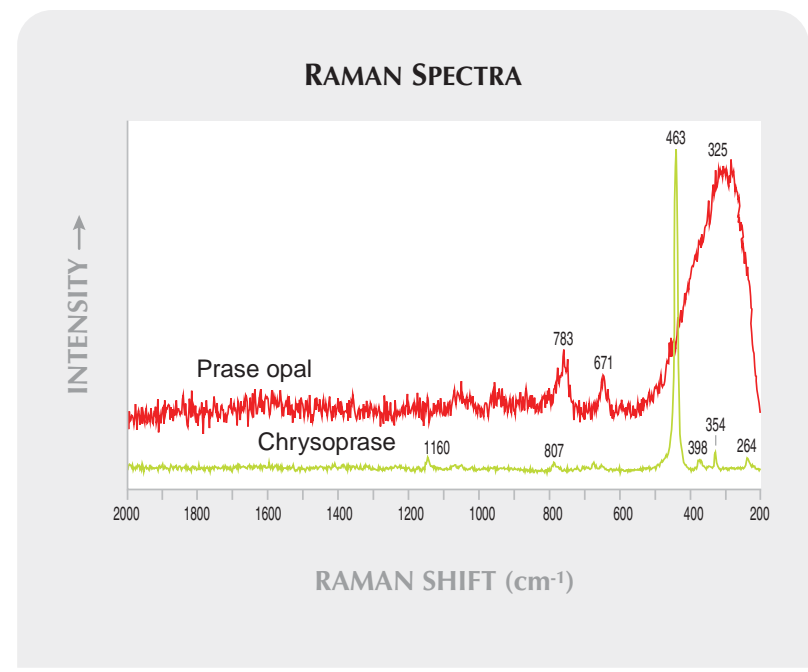

Figure 11. The Raman spectra for the chrysoprase and prase opal differ significantly.

\section{CONCLUSION}

Jewelry-quality chrysoprase and prase opal (figure 12) are mined from altered serpentinite near Haneti, Tanzania. The gemological properties of both materials are generally consistent with previous reports for chrysoprase and opal, and we did not find any features that distinguish them from the same materials from other localities. Chrysoprase can be separated from chrome chalcedony by the latter's yellow UV fluorescence, red Chelsea color filter reaction, and sharp absorption line at $684 \mathrm{~nm}$ seen with a spectroscope (Hyršl, 1999). Although similar in color and visual appearance, chrysoprase and prase opal from the Haneti area can be readily distinguished from one another on the basis of RI and SG values, as well as by their Raman spectra. Field observations of the mining site on Iyobo Mountain suggest good potential for future production.

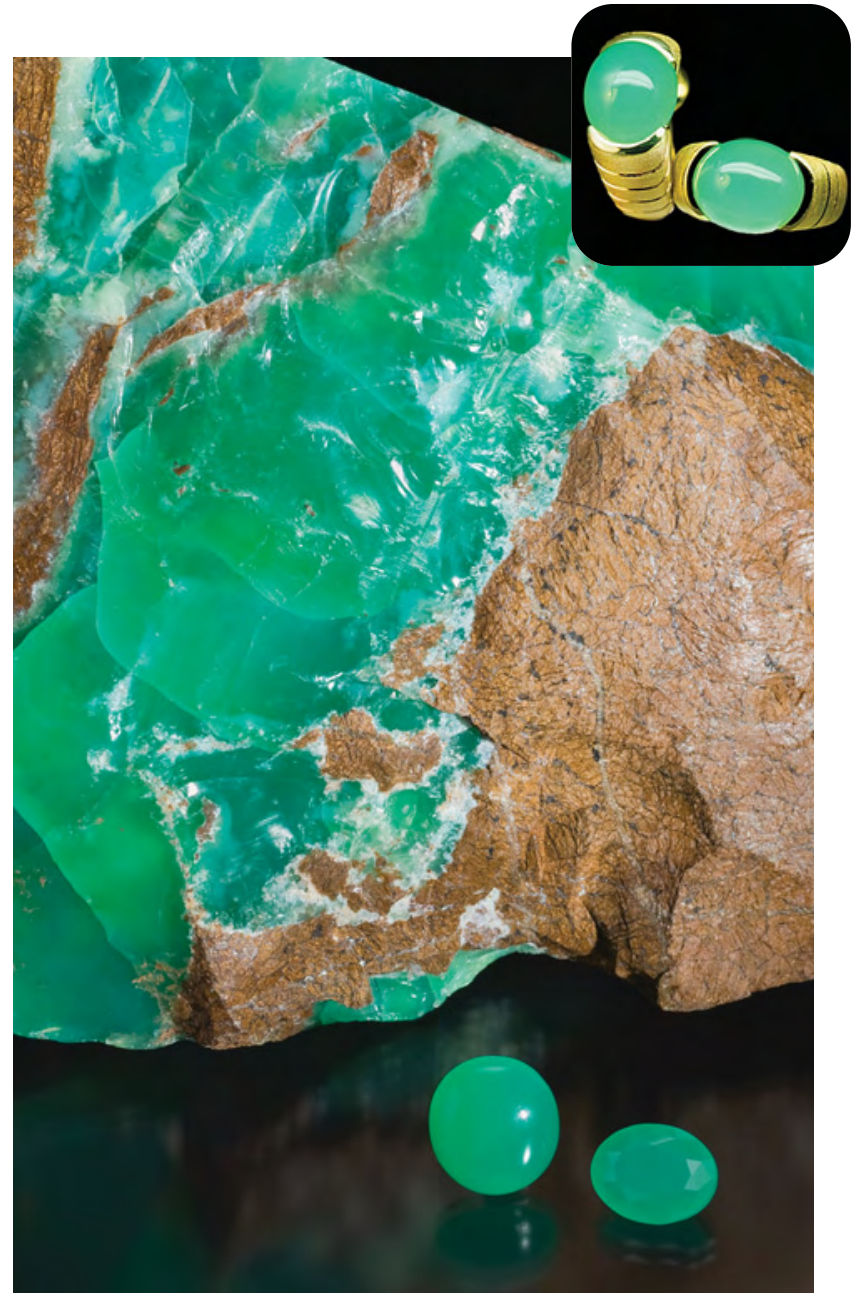

Figure 12. These Tanzanian prase opal samples consist of a $10.22 \mathrm{ct}$ cabochon and a $5.15 \mathrm{ct}$ faceted stone, together with a vein of rough material (GIA Collection nos. 32590, 32589, and 32587, respectively; photo by Robert Weldon). Tanzanian chrysoprase has been set into a variety of jewelry styles, as shown by the earrings in the inset ( 9 ct total weight; courtesy of Dimitri Mantheakis).
ABOUT THE AUTHORS

Dr. Shigley is distinguished research fellow, and Mr. Renfro is a staff gemologist, at the GIA Laboratory in Carlsbad,

California. Mr. Laurs is editor of Gems \& Gemology at GIA in Carlsbad.

\section{ACKNOWLEDGMENTS}

The two senior authors thank Dimitri Mantheakis of Ruvu Gemstone Mining Ltd., Dar es Salaam, Tanzania, for providing information, donating samples, and hosting them at his mining operation near Haneti. 


\section{REFERENCES}

Behier J. (1963) Carte Mineralogique de Madagascar. Archive Service Géologique Madagascar.

Brooks J.H. (1965) Marlborough Creek chrysoprase deposits, Rockhampton District, central Queensland. $G \uplus G$, Vol. 11, No. 11, pp. 323-330, 351.

Brown G. (2000) Australia's gemstone resources and markets. Australian Gemmologist, Vol. 20, No. 12, pp. 534-539.

Downing P.B. (2007) Candala mine chrysoprase-Seeing green in southern Queensland, Australia. Rock « Gem, Vol. 37, No. 11 , pp. 12-14, 16.

Drzymała J., Serkies J. (1973) On the lechosos opals and chrysoprases in the weathering zone of the serpentinites from Szklary (Lower Silesia). Bulletin de 1'Académie Polonaise des Sciences, Série des Sciences de la Terre, Vol. 21, No. 2, pp. $111-117$.

Duda R., Rejl L., Slivka D. (1991) Mineralien—Handbuch und Führer für den Sammler. Bechtermünz Verlag, Augsberg, Germany.

Dyrek K., Sojka Z., Žabiński W., Bozon-Verduraz F. (2001) On the problem of the occurrence of dispersed bunsenite $(\mathrm{NiO})$ in chrysoprases. Mineralogia Polonica, Vol. 32, No. 2, pp. 3-8.

Gaweł A., Olkiewicz S., Zabiński W. (1997) XRD and IR spectroscopic investigations of some chrysoprases. Mineralogia Polonica, Vol. 28, No. 1, pp. 43-51.

Gübelin E. (1975) The Color Treasury of Gemstones. Thomas Y. Crowell Co., New York, 138 pp.

Heflik W., Kwiecińska B., Natkaniec-Nowak L. (1989) Colour of chrysoprase in light of mineralogical studies. Australian Gemmologist, Vol. 17, No. 2, pp. 43-46, 58-59.

Henn U., Milisenda C.C. (1997) Zitronen-Chrysoprase aus Australien. Gemmologie: Zeitschrift der Deutschen Gemmologischen Gesellschaft, Vol. 46, No. 1, pp. 45-47.

Hyršl J. (1999) Chrome chalcedony-A review. Journal of Gemmology, Vol. 26, No. 6, pp. 364-370.

Hyršl J., Petrov A. (1998) Gemstones and ornamental stones from Bolivia: A review. Journal of Gemmology, Vol. 26, No. 1, pp. 41-47.

Johnson M.L., Koivula J.I., Eds. (1996) Gem News: Quartz-magnesite rock, so-called lemon chrysoprase, from Australia. $G \oplus G$, Vol. 32, No. 3, p. 217.

Jones B. (1992) Chrysoprase. Rock « Gem, Vol. 22, No. 12, pp. 32-34, 84-85.

- (1994a) Australian chrysoprase-The finest gem green specimens ever found come from down under. Rock $\oplus$ Gem, Vol. 24, No. 12, pp. 60-62, 64, 68-69.

(1994b) The greening of Australia. Lapidary Journal, Vol. 47, No. 11, pp. 71-72, 74, 77-79.

Kammerling R.C., Koivula J.I., Fritsch E. (1990) An examination of chrysoprase from Goias[sic], Brazil. Australian Gemmologist, Vol. 17, No. 8, pp. 313-315.

Kingma K.J., Hemley R.J. (1994) Raman spectroscopic study of microcrystalline silica. American Mineralogist, Vol. 79, No. 3/4, pp. 269-273.

Kinnunen K.A., Malisa E.J. (1990) Gem-quality chrysoprase from Haneti-Itiso area, central Tanzania. Bulletin of the Geological Society of Finland, Vol. 62, Pt. 2, pp. 157-166.

Koivula J.I., Fryer C.W. (1984) Green opal from East Africa. $G \uplus G$, Vol. 20, No. 4, pp. 226-227.

Krosch N.J. (1990) Queensland chrysoprase. Australian Gemmologist, Vol. 17, No. 8, pp. 303-306.

Langer K., Flörke O.W. (1974) Near infrared absorption spectra $\left(4000-9000 \mathrm{~cm}^{-1}\right)$ of opals and the role of "water" in these
$\mathrm{SiO}_{2} \bullet \mathrm{nH}_{2} \mathrm{O}$ minerals. Fortschritte der Mineralogie, Vol. 52, No. 1, pp. 17-51.

Mikhailov B.M. (2000) Nickel ores in the Urals. Lithology and Mineral Resources, Vol. 35, No. 4, pp. 351-364.

Mindat.org (2009) Chrysoprase. www.mindat.org/min-952.html [date accessed 10/15/09].

Nagase T., Akizuki M., Onoda M., Sato M. (1997) Chrysoprase from Warrawanda, Western Australia. Neues Jahrbuch für Mineralogie, Monatshefte, No. 7, pp. 289-300.

Natkaniec-Nowak L., Heflik W., Sobczak N., Sobczak T. (1989) Ein Beitrag zur Farbe niederschlesischer Chrysoprase. Zeitschrift der Deutschen Gemmologischen Gesellschaft, Vol. 38 , No. 1, pp. 31-36.

Niśkiewicz J. (1982) Geological setting of the occurrence of chrysoprase and related gem-stones in the Szklary Massif, Lower Silesia. Geologica Sudetica, Vol. 17, No. 1/2, pp. 125-139 [in Polish with English abstract].

O'Brien P. (1997) Praise the 'prase'! Australian Gold, Gem e) Treasure, Vol. 12, No. 1, pp. 36-37, 39-41.

O'Donoghue M., Ed. (2006) Gems-Their Sources, Descriptions and Identification, 6th ed. Butterworth-Heinemann, Oxford, UK, pp. 307-308.

Osmond R., Baker D. (2009) Chrysoprase chalcedony: Marlborough District, Queensland, Australia. www.coloredstone.com/stories/jan09/chrysoprase.cfm.

Ostrooumov M., Fritsch E., Lasnier B., Lefrant S. (1999) Spectres Raman des opals: Aspect diagnostique et aide à la classification. European Journal of Mineralogy, Vol. 11, No. 5, pp. 899-908.

Phillips G., Brown G. (1989) Mtorolite. Australian Gemmologist, Vol. 17, No. 5, pp. 205-207.

Prase opal in California (1936) Rocks e) Minerals, Vol. 11, No. 8, p. 117.

Rossman G.R. (1994) Colored varieties of the silica minerals. In P.J. Heaney, C.T. Prewitt, and G.V. Gibbs, Eds., SilicaPhysical Behavior, Geochemistry and Materials Applications, Mineralogical Society of America, Reviews in Mineralogy, Vol. 29 , pp. 433-467.

Rossman G.R. (2009) Chrysoprase, Tulare County, California. Mineral spectroscopy server, http://minerals.caltech.edu/files/ Visible/quartz/chrysoprase17884.gif [date accessed 10/15/09].

Sachanbiński M., Janeczek J., Platonov A., Rietmeijer F.J.M. (2001) The origin of colour of chrysoprase from Szklary (Poland) and Sarykul Boldy (Kazakhstan). Neues Jahrbuch für Mineralogie, Abhandlungen, Vol. 177, No. 1, pp. 61-76.

Schmetzer K., Berdesinski W., Krupp H. (1976) Grüner opal aus Tansania. Der Aufschluss, Vol. 27, No. 11, pp. 381-384.

Smallwood A. (2000) A preliminary investigation of precious opal by laser Raman spectroscopy. Australian Gemmologist, Vol. 20, No. 9, pp. 363-366

Sojka Z., Witkowski S., Żabiński W., Dyrek K., Bidzińska E. (2004) TPR, EPR and UV-Vis studies of Ni(II) speciation in chrysoprase. Neues Jahrbuch für Mineralogie, Monatshefte, No. 1, pp. 11-25.

Webster R. (1994) Gems: Their Sources, Descriptions and Identification, 5th ed. Edited by P. G. Read, ButterworthHeinemann, Oxford, UK.

Willing M.J., Stocklmayer S.M. (2003) A new chrome chalcedony occurrence from Western Australia. Journal of Gemmology, Vol. 28, No. 5, pp. 265-279.

Wittern A. (2001) Mineralfundorte und ihre Minerale in Deutschland [A Guide to Locations for Collecting Minerals in Germany]. E. Schweizerbart'sche Verlagsbuchhandlung, Stuttgart, Germany. 